\title{
先進複合材料の強化形態としての繊維中間製品 プリフォームへの期待
}

村山邦彦

\section{1. 先進複合材料の特徵}

炭素繊維などの高性能強化繊維を利用した先進複 合材料 (Advanced Composite Materials:略称 ACM) は, 各種構造部材の軽量化に対し高いポテン シャルを有するところから, 航空機・宇宙構造物へ の広範な適用に始まり, 最近では多くの高級スポー ッ・レジャ一用品類へと，その用途を拡大しつつあ る. 軽量化の指標となる比強度（引っ張り強さ/密 度）・比剛性（ヤング率/密度）によって, 炭素繊維 を高張力鋼およびジュラルミンと比較すると，比強 度は炭素繊維の高強度グレードでこれらの金属の 20 倍に達するものがあり，比剛性む高剛性グレードで は約10倍になる．しかも熱膨張係数が炭素瀻維の場 合 0 に近い，従って，これらの高強度・高剛性炭素 繊維をエポキシ樹脂などのマトリックスで複合化 し, 成形すると, 超軽量で寸法安定性の極めて高い 構造部材が得られる可能性があるということにな る.すなわち，これまで自重だけで壊れたり，撓み が大きくて使えない，あるいは，わずかな熱歪みで も実用上の支障になるような用途にも構造材として 適合し得るため, ACM は航空宇宙以外の応用分野 においてあ充分検討に值する材料といえるであろ う.

ここで，工業的な複合材料としては $\mathrm{ACM} よ り ，$ はるかに歴史が長い FRP（強化プラスチックス）と の比較を行って, ACM の特徴を明らかにする. 表 1 は, 構成素材, 成形法, 従来の用途々需要量, 利用
されている特性および克服すべき問題点の各項目に ついて,この両者を対比したあのである。

FRP は，作りやすく，功使いやすい材料であ る. 構造材料として特に強いわけではないが，腐ら ない特性が利用されて，これまで屋外用途を中心に 需要を伸ばしてきた。しかし，現在，この腐らない ことと, 再生利用の難しさから, 環境問題の悪玉に なっていることは周知のとおりである．FRP の製 造に要するエネルギーが小さいという特長を今後も 我々の産業社会で活用していくため, 抜本的な解決 策が待たれるところである.

それに対して ACM は, 構成素材である強化材お よびマトリックスのバラエティの豊富さと，その高 性能・多機能性が際立っている一方で，一般的民生 品, 公共構造物などへの用途拡大を阻害する多くの 問題も抱えている，本稿では，高い耐熱性が要求さ れない応用分野のみを対象とし，以下，プラスチッ クス系複合材料，すなわち，熱硬化性樹脂または熱 可塑性樹脂をマトリックスとするむのに絞って話を 進めることにする，その場合，強化材としては， マ トリックス樹脂との複合化の容易さ，コスト/パフ オーマンスなどから考えて, 炭素繊維およびアラミ ド繊維，それに FRP で使われているガラス繊維が 主な検討の対象になるが，ACMにおいては，繊維 の特性を最大限に活用するためこてれらを長織維で 展伸状態にして用いるところに特徴がある。また， $\mathrm{ACM}$ は高性能を極限まで求めるため, 繊維体積含 有率 $\left(\mathrm{V}_{\mathrm{f}}\right)$ が FRP の 30\%程度，あるいは，それ以下 
表 1 F R P と A C Mの特徵の比較

\begin{tabular}{|c|c|c|}
\hline & F R P & $\mathrm{ACM}$ \\
\hline (1) 構成素材 & & \\
\hline 一強化材 & 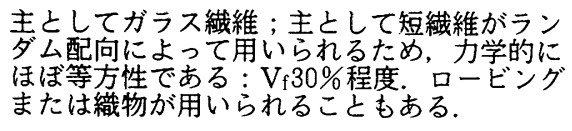 & 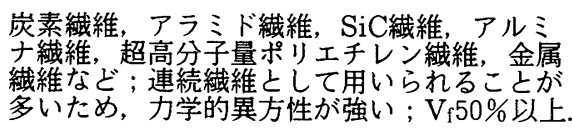 \\
\hline しマトリックス & $\begin{array}{l}\text { 従来は熱硬化性樹脂; 主として不飽和ポリエ } \\
\text { ステル(無機粉末か充坞として混合利用さ } \\
\text { れることが多い) }\end{array}$ & 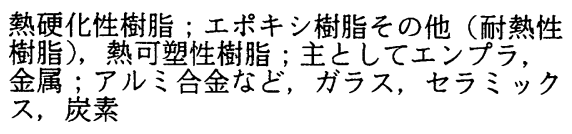 \\
\hline (2) 成形法 & $\begin{array}{l}\text { ハンドレイアップ, スプレーアップ, SMC } \\
\text { BMC, レジイイシジェクション, FW, プル } \\
\text { トルージョン }\end{array}$ & $\begin{array}{l}\text { UDまたは織物プリプレグの積層/オートータ } \\
\text { レーブによる硬华, FW, FW } \\
\text { ホットプレスなど }\end{array}$ \\
\hline $\begin{array}{l}\text { (3) 従来の用途亡需 } \\
\text { 要量 }\end{array}$ & 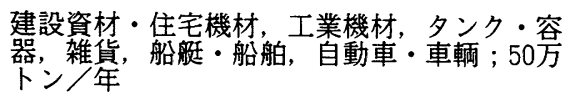 & $\begin{array}{l}\text { 航空機, 宇宙機器, 甭ポーツ・レジャー用品, } \\
\text { そ他; } 1 \text { 方 }\end{array}$ \\
\hline $\begin{array}{l}\text { （4）利用されている } \\
\text { 特性 }\end{array}$ & $\begin{array}{l}\text { 耐食性, 賦形性, 構造強度, 軽量性, 低コス } \\
\text { - 高生産性, 透光性, 電気絶䋑性 }\end{array}$ & $\begin{array}{l}\text { 超軽量性(高比剛性, 高比強度), 耐熱性, 高 } \\
\text { 精度洼定性, 耐疲学性, 振動減袁性, } \\
\text { 電波反射性, X線透過性な乏゙ }\end{array}$ \\
\hline (5) 克服すべき問題 & リサイクル性 & 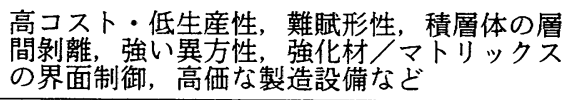 \\
\hline
\end{tabular}

に対し，これを積層体として成形する場合，少なく とも50\%程度になるように, 可能な限り繊維を高密 度に集積していく. 従って, 実際にはCFRP と表わ されることあ多いが, ACM はプラスチックス材料 というより，樹脂で固められた繊維集合体と呼ぶべ きものであり，FRP とはその構成の主体が異なる.

さらに ACM にとって重要な点は, 展伸状態の長 繊維で強化することに伴う力学的異方性の問題であ る. 平面を $60^{\circ}$ あるいは $45^{\circ}$ 交差で等しく分割した 3 軸または 4 軸配向の繊維強化複合材料では, 面内の 剛性が等方的になるが，ある特定の方向について は, UD (1 方向) 強化材より, 強化繊維を分配した だけ特性が低下している. 従って, 外部応力の方向 性に沿って最適な繊維配向設計を行い, 積極的にこ の力学的異方性を活用することが，大きな軽量化効 果につながることになる，このことが， ACM が設 計できる材料であるといわれるゆえんであるが, 換 言すればニーズオリエンテッドな材料であある.

しかし, ACM は力学的・熱的特性において大変 魅力的な材料である反面，これを実用化する上で常 に問題になるのが, 製造コスト, 賦形性および積層 体の層間剝離の問題である. 成形法としては通常, モールド面へのプリプレグの積層または FW（フィ ラメントワインディング）のあと, オートクレーブ 中で加圧・加熱する方法が採用されるが，この方法 が非常に低生産性のプロセスであるため, ACM 成 形品の高コストの原因になっている，また, 長繊維
（連続繊維）を用いるため, 材料を成形時に流動させ ることができないので，あまり複雑な形状，厚さに 变化のあるものへの対応も困難である. 層間剪断, 面外応力に対しても, 積層体は大きな弱点を持って いるので，この点であ ACM の用途が必然的に限定 されることになる.

炭素繊維の価格がメーカーの合理化努力により最 近著しく低下したにもかかわらず，航空・宇宙，ス ポーツ・レジャー分野以外で ACM の需要が伸展し ないのは, 欧米先進国でも同様である. そこで, $\mathrm{ACM}$ の特長を生かしつつ, 上述した問題点を解決 する可能性のある革新的な製造法として，あらかじ め連続纎維を用いて二アネットシェイプのプリフォ 一ムを作成し，これをモールド中に収めて RTM （Resin Transfer Molding）によって成形する方法 が最近各国で注目されている。この方法の成否の鍵 を握るのは ACM の強化形態としての繊維中間製品 ・プリフォームの開発如何であり，そのため最適材 料設計に従って立体的な繊維配向組織，すなわち三 次元繊維集合体を高効率で製造できる新しいテキス タイル技術が強く求められるわけである.

\section{2. $A C M$ の新しい応用分野}

$\mathrm{ACM}$ の用途開発を推進する目的で，そのための 基盤技術として新しいテキスタイル技術の開発を目 指そうとすると，ACM がニーズオリエンテッドな 材料であるだけに, 軽量化効果の大きい適用可能な 
構造物をある程度事前に想定しておく必要がある. 表 2 は,これまでに筆者が各種の情報源から, ACM の新しい応用分野として知り得たもの, または, 類 推したものを, (1)輸送・搬送機器, (2)建築物, 土木 工事, (3)情報通信機器, 家電製品, 精密機械, (4)工 ネルギー関連設備, (5)その他, に分類して列挙した あのである. すなわち, 顕在ニーズと潜在ニーズと いうことになるが，重要なあのが網羅されていると は限らないので，あくまで参考である。しかし， ACM による構造軽量化が省エネルギー, 環境保全, 労㗢力不足対策等々の社会的要請にマッチしたもの
であることは，これらの事例から理解できるであろ う.

ここで，材料開発の立場から，その用途がフロー 性の強いむのか， あるいはストック性の強いものか に分けて考えてみることにする.

フロー性の強い製品であれば，FRP の場合と同 様, ACMにおいても廃棄物回収システムとともに, その再生利用法が確立されねばならない，また，一 般的民生品は大量生産・大量消費されるむのである から低コスト・量産技術が不可欠になる。一方，製 品寿命が比較的短いため, 材料の耐久性はあまり大

表 2 A C Mの新しい応用分野

\begin{tabular}{l}
\hline \hline (1) 翰送・搬送機器 \\
\hline (a) 鉄道 \\
超高速鉄道, リニアモーターカーの車体, 台車枠, 動力伝達軸 \\
(b) 自動車 \\
乗用車, 業務用自動車, 特殊車両のボディ, エンジンまたは電池 \\
(c) 船舶 \\
貨物専用高速船艇の船体 \\
(d) エレベータかご, エスカレーターステップ \\
(e) ロボットアーム, クレーンアーム
\end{tabular}

（2）建築物，土木工事
(a) 超高層建筑
カーテンウォール，断熱壁
(b) 大形ドーム構造
桁材, 膜材
(c) 橋梁構造物
超長大橋, 鉄橋, 歩道橋の緊張ケーブル, プレストレストコンクリート
(d) 地下・海底トンネル構造補強材
(e) 鉄道敷設用盛土地盤補強材
(f) ウォーターフロント構造補強材
(g) 簡易へリ離発着基地
(h) 高速自動車道・高速鉄道・空港用防音壁

（3）情報通信機器, 家電製品, 精密機械
(a) 送受信・中継基地 パラボラアンテナ
(b) ノートブックパソコン, 携帯電話, 携帯型ファクシミリ, ヘッドホンステレオ, ビデオカメラ
(c) クリーナー, 冷蔵庫, ルームエアコン
(d) 織維機械, 工作・組立機械, 光学機器

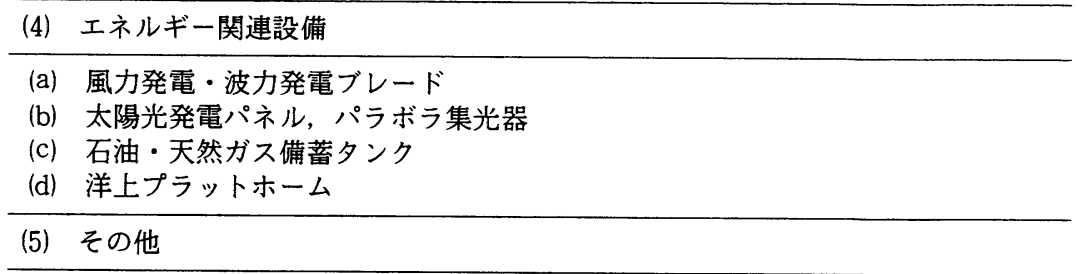
(a) 医療・福祉関係
人工筋肉, 人工骨, 関節, ウォーターベッド, 各種介助装置
(b) 農業・林業・漁業関係, 保安サービス関係なよ゙ 
きな問題にならないと考えてよいであろう．乗用 車，家電製品などの耐久消費財はここに含まれるも のである.

それに対して，ストック性の強い製品としては， 恒久的な建築物とか，公共工事による鉄道，トンネ ル，橋梁構造物などの社会的資産となるものを挙げ ることができる。これらの構造部材として ACM を 適用する場合，コスト面から現場施行技術が大変重 要になると考えられるほか，材料の長寿命化と破壊 （危険）予知診断, 補修技術の確立によって, その長 期的耐久性が保証されねばならない，ACM の耐久 性に関しては，金属あるいはコンクリートとの組み 合わせ使用に伴うさまざまな劣化現象にも充分注意 を払っておく必要がある.

このようにフローかストックかという見方で分け ようとすると，その中間的な位置付けの製品が実に 多いことに気づく、鉄道車両, 業務用自動車, エレ ベーター・エスカレーターなど，一層の省燃費・省 エネルギー化が要請されている大部分の輸送・搬送 機器は，いずれも耐用年数がかなり長いが，適当な 時期に更新されるものであり，そのためほぼ定常的 に相当量生産されているという点で航空機と類似し ている. 例えば，高速鉄道用の車体を航空機の機体 と比較すると，疲労・衝撃など動的特性に対する信 頼性が重視されるところは両者に共通しているが, 前者の方が構造の軽量化設計に多少の余裕がある反 面, 製造コストの制約はより厳しくなるという特徵 がありそうである．その他，恒久施設ではないが， ある程度長期にわたる使用を前提として設置される 建築物の防音壁・断熱壁，電波中継基地，エネルギ 一関連設備の中で分散型のものなどもここに含めて よいであろう.

構造部材として ACM が適用される可能性がある か否かは，製品の使用期間を通して構造の軽量化 が，省燃費などの直接的な効果と他の諸々の間接的 な効果によって，どれだけの経済効果を生み出す か，その経済効果に見合うコストで部材を製造でき るかにかかっていると考えられる。また，建築物の 場合には，部材の軽量化，現場施行の簡素化などに よる省力化を経済効果として見積ることになる，そ のほか, 軽量化に基づく運動性能の向上, 構造機構 部品としての高い寸法安定性, 電磁気特性などの特 有の各種機能が利用される場合にも，それぞれの経 済性が実用化の鍵になるはずである。

新しいテキスタイル技術によって, ACM の性能
を充分に活用しつつ，その製造合理化を図るための 具体的な目標として，フロー性とストック性を併せ 持つ，中間的な位置付けの製品が適していると筆者 は考えている．強化織維のプリフォームとしてはか なり大型のものになり，その形状および配向組織も 複雑であることが予想されるが，テキスタイル技術 のニューフロンティアとしてチャレンジする価値は ありそうである．また，このような開発への取り組 みには ACM の総合技術が必要とされるので，一つ の成功例が他の多くの用途開発に対し強いインセン ティブを与えることが期待できる.

\section{ACM 用繊維中間製品・プリフォー 么の技術動向}

$\mathrm{ACM}$ の成形材料として一般的に用いられている のはUD プリプレグ（1 方向引き揃えシート）であ るが，タンクを成形する場合にはヤーンを用いた $\mathrm{FW}$ 法が採用される。最近，米国において，FW で 不可能であった凹部を含む三次元曲面にも自在に対 応できる方法として，ヤーンプリプレグを用いたフ アイバープレースメント法が開発・実用化された が, 従来之同様, 成形品は積層体であり, その生産 性は低いと考えられる。

表 3 は，FRP 用を含み，また開発中のものも含 む，すべての（筆者の知る限り）強化䋐維の中間製 品・プリフォームを瀻維集合体の組織構造および織 維配向数によって（適当に）分類して示したもので ある．新しいテキスタイル技術によって，我が国に おいてす ACM の強化形態として興味深いすのがい くつか開発され，それらが以下の各論において紹介 されるので，ここではそれらを応用する立場から， 海外の動向を含めて, 注目される技術・製品につい て若干の論評を加えたい.

二次元強化に関しては，たて糸とよこ系の絡み （屈曲）による特性低下を防ぐためのノンクリンプ 織物, $\pm 45^{\circ}$ 積層時の裁断口スを防ぐためのバイヤ ス織， 1 枚の織物で面内を等方性化した 3 軸織など が開発されている．スパイラル織はたて糸の引き出 し速度に傾斜をつけ，よこ糸の挿入長さを調節しな がら，ドーナツ型の織物をらせん状に織り上げたも のであるが，その繊維配向から円錐面を積層してい くのに適している. 最近, 強化繊維を編物にして, その賦形性を生かそうとする試みがある。編物その あのは織維の折れ曲がりを特徴とするので, 筆者の 考える ACM の要件からはずれるが, 生産性などが 
表 3 強化繊維中間製品, プリフォームの種類

\begin{tabular}{|c|c|c|}
\hline \multicolumn{2}{|c|}{ 䋨維配向および構造 } & 強化織維中間製品, プリフォームの製法例 \\
\hline 二次元 & $\begin{array}{l}\text { ランダム } \\
1 \text { 朝配向 } \\
2 \text { 朝配向 } \\
3 \text { 朝配向 } \\
4 \text { 朝配向 }\end{array}$ & $\begin{array}{l}\text { チップドストランドマット(短繊維), スワールマット（連続繊 } \\
\text { 維), 不織布, よこ編・たて編 } \\
1 \text { 方向引き揃えシート } \\
\text { 平織, 朱子織, ノンクリンプ織物, バイヤス織, スパイラル織, } \\
\text { 平打ち組物 } \\
3 \text { 朝織, 平打ち組物 } \\
\text { 多朝積層布 (ラッシェル, ステッチド) }\end{array}$ \\
\hline $\begin{array}{l}\text { ソ' } \\
\text { ソ' } \\
\text { ソ' } \\
\text { ソ' } \\
\text { 張壳 } \\
\text { サン }\end{array}$ & $\begin{array}{l}3 \text { 軸 } \\
4 \text { 軸 } \\
5 \text { 軸 } \\
6 \text { 朝以上 } \\
\text { ッチ構造 }\end{array}$ & $\begin{array}{l}\text { チョップドストランド吹付け成形, ストレッチ成形（スワール } \\
\text { マット, 織物・組物・編物シート), ソックス型織物・編物, } \\
\text { FW, 丸打ち組物, 円環織, パラボラ織 } \\
\text { 多重織, 絡み織, 直交 } 3 \text { 軸織 } \\
\text { 多重織, 角打ち組物, } 4 \text { ステップブレイディング, 厚肉円筒も可 } \\
\text { 角打ち組物, } 2 \text { ステップブレイディング, 多軸積層布 } \\
\text { ピアス } \\
\text { 立体編物, } 4 \text { ステップブレイディング, 直交 } 3 \text { 軸織 } \\
\text { 立体編物, } 4 \text { ステップブレイディング, 風通織, パイル織 }\end{array}$ \\
\hline
\end{tabular}

評価されて特殊な用途を見出していくかも知れな い.

平面状の繊維中間製品でも，実際に ACM の成形 に用いる場合には，いろいろな曲面に積層していく ことが多いものである. 平織・朱子織の剪断変形に よって球を包み得ることはよく知られているが，こ の特性を利用した成形装置が開発されている，曲面 形成が可能なテキスタイル技術の例としては， FW および丸打ち組物が ACM の成形によく利用されて いるが，最近ソックス型織物および円環織がドーム 形状のプリフォームの製法として注目されている. パラボラ織は，放射方向系と円周方向糸によって， パラボラ面に沿って織り上げるあのであるが，径の 増加に伴って放射方向系を追加し, 織密度がほぼ均 一になるよう工夫されている。

前述した強化繊維による曲面形成は三次元強化の 一つの条件になるものであるが，層間に弱点を持た ない，厚さのあるプリフォームを作成するために は，これに加えて立体的に繊維を配向・配列する技 術が必要になる．すでに，三次元空間を立体幾何学 的に均等に分割した配向で組織化していくことので きる，いくつかの方法が提案されている.

直交 3 軸織は，たて糸。よこ糸・垂直糸の中の一 つを固定糸とし，残る二つの糸をレピアなどで順次 挿入して織り上げていくものであるが, 緻密な織物 では通常絡みを使わない．しかし，格子状の粗な織 物を作る場合には，系を固定するために絡みが必要 になる．また，立体的な 4 軸の組織は，組物技術に よって容易に得られる. 組物の断面形状に従って面
内に配置されたボビンの組み替え方に，いろいろな 工夫がある。 3 軸および 4 軸のいずれも厚肉円筒に 適用することが可能で，欧米において多くの試作例 がある．従来からある多重織む厚さ方向の繊維配向 を考慮すると， 3 軸または 4 軸組織とみなすことが できる。これらは平織と同様な賦形性を有すると考 えられるので, ACM 用繊維中間製品として利用さ れてもよさそうである． 3 軸および 4 軸の他に，三 次元空間を均等に分割できるものとして，6軸の繊 維配向があるが，現状では，ロッド状に成形した繊 維束をそれぞれの方向から挿し込んで組織化する以 外に適当な方法が見当たらない． 3 軸と 4 軸と 6 軸 を組み合わせて，さらに多軸化していくことも可能 であるが，6軸以上では立体的にほぼ等方性になる ことが知られている.

三次元強化において，そのほか分岐した構造，す なわち張款構造およびサンドイッチ構造を立体的な 繊維組織体として形成する方法が注目されている. たて・よこ方向に必要な幅と厚さ分の強化繊維を配 列しておき，この繊維束をたて編機で厚さ方向の糸 を供給しながら固定していくという，立体編物技術 によって，これらの試作が進められている. 特殊織 物として知られる風通織，パイル織によっても，こ れと類似の構造を織成することが可能なため，実際 に強化繊維を用いてプリフォームを作成し，ACM としての評価が行われている.これらの構造体は従 来, UD プリプレグなどをその形状に沿って積層 し，分肢部を縫製によって補強して作成していたも のである. 
このようにみてくると, 立体的な繊維配向組織, すなわち三次元繊維集合体の形成手段として用いら れているテキスタイル関連技術は，

•Weaving : 織る

- Braiding：組む

- Knitting：編む

- Stitching：縫う

- Filament Winding：巻き付ける

- Piercing：挿し込む

- Laying-down：押し当てる

ということになる. 今後, これらのインテグレーシ ョン技術が生まれてくるかもしれない.

\section{4.コンポジテックス技術発展への期 待}

コンポジテックスとは，コンポジット用のテキス タイルという意味で, TECHTEXTIL 国際見本市開 催に際して命名された名称である.

$\mathrm{ACM}$ の用途開発を推進するには,「安くて良い物 を作る」ための基盤技術を確立しなければならな い. ACM の特性改善および製造合理化にとって, 革新的な強化形態を生み出すテキスタイル技術の開 発が重要な位置を占めている。 また，新しい応用分 野は，テキスタイル技術の今後の発展を促すことに むなろう，と筆者は考えている，そこで，コンポジ テックスを応用する立場から, 今後の研究テーマ, 開発の方向付け，推進策などについて，最後にま之 めておきたい。

(1)新しい応用分野・構造部材の軽量化ニーズと必要

機能の把握

最も効果的，かつ影響度・波及性の高い用途 を探索し、フィージビリティスタディを行う。

(2)最軽量化材料設計技術の開発

$\mathrm{ACM}$ の最適設計法を二次元から三次元へ拡 張し，構造部材の形状と物性を同時に最適化す るための基礎を確立する.
(3)ACM 用繊維中間製品・プリフォームの要素技術 の吟味と拡張発展性の検討

強化織維を用いて, 既存の繊維機械によって 現状で何かできるかを明らかにするとともに， 改造によって原理的に何が可能になるかを検討 する．併せて，海外における技術動向を継続的 に調査する。

(4)三次元繊維集合体と樹脂マトリックスとの高効率 複合化技術の開発

熱硬化性樹脂の含浸過程のシミュレーショ ン, 硬化過程における内部応力の解析，および 熱可塑性樹脂の充填法, 高エネルギー密度ビー 么の利用技術，並びに現場施行法などの基礎的 検討を行う。

(5)繊維集合体の変形の幾何学, および三次元強化 ACM の力学的・熱的特性の評価

アパレルにおける布地の变形の幾何学を応用 し, 発展させる. また, 強化形態の変化に基つ く, ACM の力学的・熱的特性, その立体的異 方性を理論的・実験的に検討する.

(6)的確な開発コンセプトをまとめ, 産官学, 繊維集 合体工学と複合材料工学による学際的・業際的問 題への取り組み体制を構築する.

この度, 当学会にコンポジテックス研究会が発足 した，お世話をする者の一人として，テキスタイル および ACM の応用分野の拡大上関連業界の発展に いささかであ寄与したいと念願している。できるだ け多くの関心ある方々のご参加を望むものである.

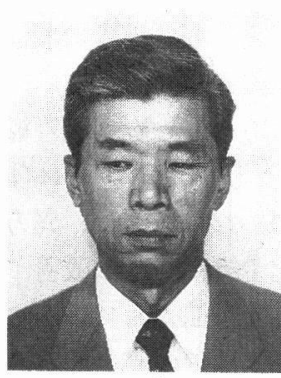

村山邦彦（むらやまくにひこ） 昭和 35 年大阪府立大学工学部応 用化学科卒, 同年三菱電機(株)入 社, 現在, 材料デバイス研究所 参事として, 繊維強化複合材料 の研究開発に従事.（三菱電機 (株), 干661 尼崎市塚口本町8-51, TEL. 06-497-7473, FAX. 06-497-7600) 